productivity with rhizosphere bacteria. Proc. 3rd Intl. Wrkshp. Plant GrowthPromoting Rhizobacteria. CSIRO Press, Adelaide, South Australia.

Egel, D.S. 2000. Evaluation of fumigants for the control of fusarium wilt and rootknot nematode of watermelon. Fungicide Nematicide Test Rpt. 2001:N19.

Florida Department of Agriculture. 1998. Florida agricultural statistics. Fla. Agr. Stat. Serv., Orlando.

Gagné, S., L. Dehbi, D. Le Quéré, F. Cayer, J-L Morin, R. Lemay, and N. Fournier. 1993. Increase of greenhouse tomato fruit yields by plant growth-promoting rhizobacteria (PGPR) inoculated into the peat-based growing media. Soil Biol. Biochem. 25:269-272.

Kokalis-Burelle, N., C.S. Vavrina, E.N Rosskopf, and R.A. Shelby. 2002. Field evaluation of plant growth-promoting rhizobacteria amended transplant mixes and soil solarization for tomato and pepper production in Florida. Plant Soil 238: 257-266.

Nemec, S., L.E. Datnoff, and J. Strandberg. 1996. Efficacy of biocontrol agents in planting mixes to colonize plant roots and control root diseases of vegetables and citrus. Crop Protection 15:735-742.

Rodríguez-Kábana, R., G. Morgan-Jones, and I. Chet. 1987. Biological control of nematodes: Soil amendments and microbial antagonists. Plant Soil 100:237-247.

Turner, J.T. and P.A. Backman. 1991. Factors relating to peanut yield increase after seed treatment with Bacillus subtilis. Plant Dis. 75:347-353

Vavrina, C.S. 1996. An introduction to the production of containerized vegetable transplants. Univ. Fla. Coop. Ext. Serv. Bul. 302.

Vavrina, C.S. 1999. The effects of LS213 (Bacilluspumilus) on plant growth promotion and systemic acquired resistance in muskmelon and watermelon transplants and subsequent field performance. Proc. Intl. Symp. Stand Establishment. p. 107-111.

Vavrina, C.S., G.J. Hochmuth, J.A. Cornell, and S.M. Olson. 1998. Nitrogen fertilization of Florida-grown tomato transplants: seasonal variation in greenhouse and field performance. HortScience 33:251-254.

Weller, D.M. 1988. Biological control of soilborne pathogens in the rhizosphere with bacteria. Annu. Rev. Phytopathol. 26:379-407.

Zeck, W.M. 1971. A rating scheme for field evaluation of root-knot nematode infestation. Pflanzenschutz 24:141-144.

\section{Arbuscular Mycorrhiza and Growth Responses of Several Ornamental Plants Grown in Soilless Peat-based Medium Amended with Coconut Dust (Coir)}

\author{
R.G. Linderman ${ }^{1}$ and
}

E.A. Davis ${ }^{2}$

ADDITIONAL INDEX WORDS. endomycor rhiza, potting mixes, marigold, minirose, zinnia, germander, lavender

SUMmary. Coconut fiber dust (coir) is being used as a peat substitute or amendment to potting mixes with varied results. However, its microbial composition and compatibility with beneficial microbes that might be added to growth media in the nursery, such as mycorrhizal fungi, has not been determined. In this study, coir was amended to a peat-based medium $(15 \%, 30 \%, 45 \%$, and $60 \%$ by volume) to determine its effects on growth of several ornamental plants and on the formation and function of the arbuscular mycorrhizal (AM) fungus Glomus intraradices. Mycorrhizae formed as well, and usually better, in all the coir-amended peat treatments as in peat alone. The magnitude of growth enhancement due to mycorrhizae was small for the plants tested in these media compared to that which usually occurs in soil-based media. In this experiment, plant growth responses appeared to be independent of level of mycorrhizal colonization and were plant species dependent. Consistent growth enhancement from mycor-

USDA, Agricultural Research Service, Horticultural Crops Research Laboratory, 3420 N.W. Orchard Avenue, Corvallis, OR 97330

The authors gratefully acknowledge the technical assistance of Karin M. Rohland. Mention of a trademark, proprietary product, or vendor does not constitute a guarantee or warranty of the product by the U. S. Department of Agriculture and does not imply its approval to the exclusion of other products or vendors that also may be suitable.

${ }^{1}$ Research plant pathologist, corresponding author; e-mail lindermr@science.oregonstate.edu.

${ }^{2}$ Faculty research assistant, Dept. of Botany and Plant Pathology. Oregon State University. rhizae only occurred with marigold (Tagetes patula). With germander (Teucrium fruticans), growth was depressed with mycorrhizal inoculation in the medium composed of $60 \%$ coir. Growth of lavender (Lavandula augustifolia) was depressed in all coir-amended media, with or without AM inoculation, compared to the nonamended control. These results confirm previous reports of varied response of plant species to coir, and indicate the lack of any detrimental effects of coir on mycorrhiza formation.

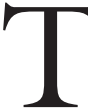
he use of coir as a suitable plant growth substrate has been reported for many greenhouse plants: rose (Rosa spp.) (Raviv et al., 2001); australian native pea (Pultenaea spp.), australian native aster (Brachycome spp.), australian native correa (Correa spp.), eucalypt (Eucalyptusspp.), spider flower (Grevillea spp.), and australian native lomandra (Lomandra spp.) (Offord et al., 1998); tickseed (Coreopsis spp.) and tomato (Lycopersicon spp.) (Pill and Ridley, 1998); arrowwood (Viburnum spp.) and lilac (Syringa spp.) (Evans and Iles, 1997); dumb cane (Dieffenbachia spp.), madagascar dragon tree (Dracaenaspp.), and peace lily (Spathiphyllum spp.) (Stamps and Evans, 1997, 1999); rhododendrons (Rhododendron spp.) (Knight et al., 1998); balsam (Impatiens spp.) (Argo and Biernbaum, 1997); jungle geranium (Ixora spp.) and star cluster (Pentas spp.) (Meerow, 1994); sunflower $(\mathrm{He}$ lianthus spp.), marigold (Tagetes spp.), petunia (Petunia $\times$ bybrida), and geranium (Pelargonium spp.) (Evans and Stamps, 1994); poinsettia (Euphorbia spp.) and lily (Lilium spp.) (Argo and Biernbaum, 1995; Waber and Evans, 1996); tailflower (Anthurium spp.) and magesty palm (Raveneaspp.)(Meerow, 1995 ).

Most reports indicate that coir is suitable for potting mixes, but reported growth responses are as varied as the plant species grown, the potting substrate mixes, the fertilizer regime, the type of peatmoss used in the mix (i.e., sphagnum versus sedge) (Meerow, 1994, 1995), and the actual sources of the coir (Abad et al., 2002; Evans et al., 1996; Konduru et al., 1999). This last factor may be one of the most crucial; the live coconut plantation site and the coir process of drying, grinding, and compression can significantly affect 
its physical and chemical properties (Konduru et al., 1999). Of the chemical constituents, exchangeable salts are the most variable, affected primarily by levels of potassium $(\mathrm{K})$, sodium $(\mathrm{Na})$, and chlorine $(\mathrm{Cl})$, which are now known to be inherently high in the long husk fibers themselves. Additionally, the proximity of the coir storage to the ocean influences the salt accumulation from coastal spray.

Growers of nursery crops are increasingly interested in biologicallybased approaches to plant production that reduce the use of high rates of chemical fertilizers and pesticides. Mycorrhizal fungi form a symbiotic relationship with the roots of most plants and provide increased fertilizerand water-use efficiency. Mycorrhizae also enhance resistance to diseases (Linderman, 1994, 2000) and soil toxicities, such as salinity (Cantrell and Linderman, 2001), improve transplantability (Biermann and Linderman, 1983a; Chang, 1992) and cause earlier flowering (Hunter, 1997). Arbuscular mycorrhiza (AM) is the predominant association on most cultivated plants. Certain tree species form ectomycorrhizae [such as oaks (Quercus spp.), pines (Pinus spp.), firs (Abies spp.), eucalypts (Eucalyptusspp.), birches (Betulaspp.), and beeches (Fagus spp.)] (Brundette, 1991) and ericaceous shrubs or berries (e.g., Rhododendron spp., Vaccinium spp.) form ericoid mycorrhizae (Smith and Read, 1997).

Mycorrhizae are very common and often are essential components of most ecosystems. However, mycorrhizae are rarely present in soilless media used in container nurseries. If growth media have soil included, the soil could carry inoculum or it could be introduced as an airborne contaminant in dust. But consistent presence of mycorrhizae in containers is rare without intentional inoculation and management by the grower.

Media containing peatmoss as a major component have been shown to suppress AM fungal establishment. Different peats have been shown to cause varied extent of suppression of the AM association (Linderman and Davis, 2003). It has been thought that suppression may be due to the heavy rates of fertilizer application to these mixes (Biermann and Linderman, 1983b), but other factors might also be involved. A high rate of phosphorus $(\mathrm{P})$ in potting mixes suppresses AM fungi (Datnoff et al., 1991). Slowly available sources of $P$, such as rock phosphate (Graham and Timmer, 1984), some composts (Linderman and Davis, 2001), or organic fertilizer sources appear to be more conducive to AM establishment than high rates of soluble, inorganic fertilizers that often have high levels of $\mathrm{P}$.

The purpose of this study was to determine if adding coir to peat would affect the formation and activity of AM fungi. We examined the effects of coir amended to a peat-based soilless medium on AM fungal colonization and plant growth of five different ornamental plants.

\section{Materials and methods}

Preparation AND Biological MaTERIALS. This experiment included 10 treatments of five coir rates and two AM fungal inoculum levels combined in a $5 \times 2$ factorial arrangement. Each treatment was tested using five different plant species: 'Lady' lavender, germander, 'Aurora Light Yellow' marigold, 'Peter Pan Scarlet' zinnia (Zinnia elegans), and 'Orange Cupido' [PP10820] miniature rose.

Coir (CocoLite; Coconut Palm Resources, Hillsboro, Ore.) was mixed manually with peatmoss (Lakeland Peat; Sun Gro Horticulture, Inc., Hubbard, Ore.) at rates of $0,15,30,45$, and $60 \%$. As each coir-peat treatment was mixed, horticultural grade perlite (Supreme Perlite, Portland, Ore.) was added at $20 \%$ of total volume of the mix along with dolomitic limestone at $2.97 \mathrm{~kg} \cdot \mathrm{m}^{-3}\left(5 \mathrm{lb} /\right.$ yard $\left.^{3}\right)$. Mixes were stored in plastic waste containers until used for planting.

Square plastic pots $[10.2 \mathrm{~cm}(4$ inches)] were filled with each substrate [about $0.6 \mathrm{~L}(0.63 \mathrm{qt})$ ] and leached to remove excess salts by irrigation with tap water from a hose until gravimetric water was released from the bottom of the pot. Each pot was leached twice before AM fungal inocula were applied and two times more before any experimental plants were transplanted.'

Lavender, marigold, and zinnia seeds were germinated in plug flats containing a 60 peat : 30 sandy loam : 10 perlite mix (by volume). The loam was pasteurized with aerated steam [30 min at $\left.60^{\circ} \mathrm{C}\left(140.0^{\circ} \mathrm{F}\right)\right]$ to eliminate pathogens and mycorrhizal fungi. Seedlings were transplanted (one plant per pot) when two true leaf pairs had formed, at about 5 weeks, 2 weeks, and 4 weeks from germination, respectively. Two- node cuttings of miniature rose and germander were stuck in Oasis cubes (Smithers-Oasis USA, Kent, Ohio) and placed under mist until two to three roots formed on each.

Half of all coir-peat treatments were inoculated with the AM fungus Glomus intraradices which previously had been pot-cultured with 'Guardsman' bunching onions (Allium cepa) grown in 1:1 loam:sand. Inoculum for the study consisted of a mixture of the soil medium, extraradical hyphae and spores, and colonized root segments [ $\leq 4 \mathrm{~mm}(0.16$ inch $)$ in length]. Evaluation of the inoculum potential of $G$. intraradices before the study, using the most probable number method (Woomer, 1994), indicated that the soil medium had 11 propagules $/ \mathrm{cm}^{3}$ (180 propagules/inch ${ }^{3}$ ). The remaining containers received non-mycorrhizal inoculum produced in the same manner as was used for G. intraradices inoculum production but without inoculating with AM fungi. In all treatments, $5 \mathrm{~cm}^{3}$ (about 1 teaspoon) of the appropriate inoculum were placed in the middle of a pot just under the transplant zone.

To standardize qualitatively the rhizosphere soil microflora of the AM treatments, root washings from the pot cultures were applied to pots after being passed through a 38-um sieve (Tyler equivalent 400-mesh) and Whatman \#1 filter paper. Across all coir-peat rates, control pots each received $50 \mathrm{~mL}$ (1.7 fl oz) of $G$. intraradices filtrate, and $G$. intraradices-inoculated pots received $50 \mathrm{~mL}$ of non-mycorrhizal plant soil filtrate. These solutions were applied 2 to $3 \mathrm{~d}$ before any transplant.

GROWTH AND HARVEST. After transplanting, plants were lightly moistened and placed on greenhouse benches. Pots were arranged in a randomized complete-block design with 6 to 8 replications per treatment. Greenhouse controls were maintained at $27 / 18^{\circ} \mathrm{C}$ $\left(80.6 / 64.4^{\circ} \mathrm{F}\right)$ day/night temperatures and supplemental lighting by high-pressure multi-vapor lamps provided 14 -h daylengths of 600 to $800 \mu \mathrm{mol} \cdot \mathrm{m}^{-2} \cdot \mathrm{s}^{-1}$ at canopy level (from beginning to end of each study). All plants were fertilized once or twice weekly, depending on the plant species and coir-peat ratio. Beginning $6 \mathrm{~d}$ after transplanting, plants were fertigated using soluble $13-2-13$ (13N-0.9P-10.8K) fertilizer (Plant Marvel; Plant Marvel Laboratories, Inc., Chicago), providing $200 \mathrm{mg} \cdot \mathrm{L}^{-1}$ (ppm) nitrogen $(\mathrm{N})$ and $\mathrm{K}$, and 16 
$\mathrm{mg} \cdot \mathrm{L}^{-1} \mathrm{P}$. Between scheduled fertilizations, additional selective watering of individuals was necessary depending upon the coir-peat ratio and plant age. Coir-amended mixes are known to have higher moisture holding capacities than peat-based mixes (Stamps and Evans, 1997) and we typically watered or fertilized the higher coir-peat treatments at one-third the frequency needed for no-coir or low coir-peat treatments. Fertilizer or water was applied in excess to ensure complete drainage through the pot.

Plants were harvested when they reached marketable liner size. Tops of plants were cut at the soil line and dried in a convection drying-oven at $65{ }^{\circ} \mathrm{C}$ $\left(149.0^{\circ} \mathrm{F}\right.$ ) for $48 \mathrm{~h}$. Roots were washed clean of potting mix, blotted dry on paper towels, weighed, and each one randomly subsampled and evaluated microscopically for mycorrhizae, then re-weighed and oven-dried for final dry weights.

Portions of roots sampled for mycorrhizal evaluation were cleared and stained by a modified Phillips and Hayman (1970) technique, replacing lacto-phenol with lacto-glycerin. Stained roots were arranged on a grid with $1 \mathrm{~cm}(0.4$ inch $)$ sections, and then 100 intersections per sample were examined for the presence or absence of vesicles and/or arbuscules (Giovanetti and Mosse, 1980).

Data from individual host bioassays were tested by multiway analysis of variance (Systat 8.0; SPSS, Inc., Chicago). Treatment means were compared where appropriate using Fisher's protected least significant difference test at $P \leq$

\subsection{5 .}

Chemical analyses of coir, colrPEAT MixTURES AND leAchates. Four different sources of coir were analyzed for chemical properties by the Central Analytical Services at Oregon State University, Corvallis for comparative purposes and to select one for further testing. They varied substantially in electrical conductance (EC), and content of iron $(\mathrm{Fe})$, manganese $(\mathrm{Mn})$, copper $(\mathrm{Cu})$, zinc $(\mathrm{Zn})$, chlorine $(\mathrm{Cl})$, and $\mathrm{N}$. CocoLite, a blend from Sri Lanka, was selected for the reported study, to be used in various combinations with a peat-based medium. Analyses of preplant mixes and post-harvest residuals of unplanted containers are shown in Table 1.

Leachates of unplanted containers of each of the mixes were collected at the time of the initial saturation, at transplant, and at harvest, and were analyzed as well by the Central Analytical Services at Oregon State University (Table 2). Three replicate samples of leachates from each treatment were collected separately and then pooled for analysis, thus precluding any statistical analysis.

\section{Results and discussion}

Chemical analyses of the different coirs (data not presented) substantiated other reports on the variability in coir sources (Abad, et al., 2002; Evans, et al., 1996; Handreck, 1993; Meerow, 1994; Noguera, et al., 1997) including high concentrations of $\mathrm{K}, \mathrm{Na}$, and $\mathrm{Cl}$. Analyses of our coir-peat mixes indicated increasingly high levels of $\mathrm{K}, \mathrm{Na}$, and $\mathrm{Cl}$ with increased coir content (Table $1)$, consistent with previous reports.
Leachate analyses (Table 2) paralleled this trend, with high concentrations of $\mathrm{Cl}$ being leached after initial saturation. By the time of transplant (after two leachings), however, $\mathrm{Cl}$ content was substantially reduced, while $\mathrm{K}$, calcium $(\mathrm{Ca})$, magnesium $(\mathrm{Mg}), \mathrm{Cu}$, and nitrate $\left(\mathrm{NO}_{3}^{-}\right)$increased.

Coir typically has a lower cation exchange capacity (CEC) and higher $\mathrm{pH}$ relative to peat (Abad et al., 2002), but there are conflicting reports about the nature of its buffering capacity. Handreck (1993) claimed that coir has a low ability to retain cations, low $\mathrm{pH}$ and buffer capacity, and suggested that additional $\mathrm{N}, \mathrm{Ca}$, sulfur (S), $\mathrm{Cu}$, and $\mathrm{Fe}$ was needed to bring the media to adequate supply levels. However, Kithome et al. (1999) used an isotherm model to show that given its surface area and the types of functional groups that affect its CEC, coir has the ability to absorb considerable amounts of ammonium $\left(\mathrm{NH}_{4}^{+}\right)$, and, depending upon whether it is acidified or deprotonized, its CEC can be decreased or increased. This reaction would be influenced by the nature of fertilizer application and starter charges to the growth medium. In ourstudy, initial mixes contained lower $\mathrm{NH}_{4}{ }^{+}$with increased coir rates (Table 1).After harvest, the same solid samples contained lower amounts of $\mathrm{NH}_{4}^{+}$in the lower coir rates but slightly elevated amounts as the rates increased.

At harvest, $\mathrm{Kand} \mathrm{NO}_{3}{ }^{-}$concentrations were further elevated in both residual soil and leachates (Tables 1 and 2 ). This is likely a reflection of the exchange capacities of the mixes throughout the water-fertilizer regime applied to the

Table 1. Chemical analyses ${ }^{z}$ of coir-peat mixes, the coir (CocoLite), and peat used in the current study, analyzed before planting (initial mixes) and at the time of harvest but without plants (at harvest).

\begin{tabular}{|c|c|c|c|c|c|c|c|c|c|c|c|c|c|c|c|c|c|}
\hline \multirow{2}{*}{$\begin{array}{l}\text { Coir-peat } \\
\text { treatment }^{\mathrm{y}}\end{array}$} & \multirow[b]{2}{*}{$\mathrm{pH}$} & $\mathbf{P}$ & $\mathbf{K}$ & $\mathrm{Ca}$ & $\mathrm{Mg}$ & $\mathrm{Na}$ & CEC & EC & $\mathrm{Fe}$ & Mn & $\mathrm{Cu}$ & $\mathrm{Zn}_{\mathbf{n}}$ & $\mathrm{NH}_{4}-\mathrm{I}$ & $\mathrm{NO}_{3}-\mathrm{N}$ & $\mathrm{Cl}$ & TC & $\mathrm{TN}$ \\
\hline & & \multicolumn{2}{|c|}{$\left(\mathrm{mg} \cdot \mathrm{kg}^{-1}\right)^{\mathrm{x}}$} & & \multicolumn{2}{|c|}{$\left(\mathrm{cmol} \cdot \mathrm{kg}^{-1}\right)^{\mathrm{x}}$} & \multicolumn{2}{|r|}{$\overline{\left(d S \cdot m^{-1}\right)^{x}}$} & \multicolumn{7}{|c|}{$\left(\mathrm{mg} \cdot \mathrm{kg}^{-1}\right)^{\mathrm{x}}$} & \multicolumn{2}{|c|}{$\left(\mathrm{g} \cdot \mathrm{kg}^{-1}\right)^{\mathrm{x}}$} \\
\hline \multicolumn{18}{|l|}{ Initial mixes } \\
\hline $0: 100$ & 5.3 & 22 & 115 & 15.3 & 4.2 & 0.30 & 54.7 & 0.4 & 187 & 160 & 1.22 & 9.4 & 93.1 & 24.9 & 99 & 353 & 8.1 \\
\hline $15: 85$ & 5.8 & 32 & 317 & 19.1 & 5.2 & 0.70 & 67.0 & 0.6 & 221 & 88 & 1.40 & 7.9 & 58.2 & 38.2 & 418 & 378 & 10.1 \\
\hline $30: 70$ & 5.9 & 24 & 678 & 18.6 & 5.1 & 1.35 & 55.8 & 0.7 & 167 & 51 & 1.47 & 6.9 & 9.5 & 4.4 & 901 & 367 & 9.1 \\
\hline $45: 55$ & 6.0 & 19 & 910 & 19.2 & 5.5 & 1.73 & 56.6 & 0.7 & 155 & 35 & 1.24 & 7.0 & 7.6 & 1.2 & 1153 & 355 & 8.6 \\
\hline $60: 40$ & 6.2 & 24 & 1350 & 19.3 & 5.8 & 2.51 & 75.9 & 1.0 & 131 & 23 & 1.33 & 9.2 & 5.2 & 1.0 & 1135 & 358 & 7.7 \\
\hline CocoLite $^{w}$ & 5.6 & 51 & 7995 & 7.0 & 8.6 & 8.78 & 57.3 & 0.9 & 52 & 10 & 1.30 & 4.83 & 23.3 & 0.5 & 4305 & 472 & 5.0 \\
\hline Peat $^{w}$ & 4.7 & 27 & 101 & 36.8 & 16.4 & 0.28 & 121.0 & 0.6 & 600 & 112 & 4.00 & 6.60 & 114 & 110 & 264 & 471 & 13.8 \\
\hline \multicolumn{18}{|l|}{ At harvest } \\
\hline $0: 100$ & 5.3 & 119 & 927 & 12.8 & 4.5 & 0.46 & $\mathrm{n} / \mathrm{a}$ & 6.3 & 172 & 67 & 4.44 & 12.2 & 19.5 & 2675 & 229 & 281 & 10.3 \\
\hline $15: 85$ & 5.9 & 79 & 1170 & 18.1 & 6.0 & 0.66 & $\mathrm{n} / \mathrm{a}$ & 4.0 & 93 & 28 & 3.69 & 11.3 & 11.9 & 2955 & 334 & 332 & 12.6 \\
\hline $30: 70$ & 6.1 & 69 & 2680 & 29.8 & 10.5 & 1.94 & $\mathrm{n} / \mathrm{a}$ & 5.2 & 58 & 27 & 3.42 & 14.5 & 11.1 & 3976 & 827 & 318 & 13.0 \\
\hline $45: 55$ & 6.2 & 69 & 2940 & 29.6 & 10.5 & 2.45 & $\mathrm{n} / \mathrm{a}$ & 4.7 & 47 & 18 & 3.20 & 12.4 & 11.7 & 3971 & 1011 & 339 & 13.4 \\
\hline $60: 40$ & 6.4 & 55 & 2690 & 27.3 & 9.3 & 2.31 & $\mathrm{n} / \mathrm{a}$ & 4.4 & 35 & 19 & 3.84 & 12.1 & 9.6 & 3538 & 890 & 333 & 11.6 \\
\hline
\end{tabular}

${ }^{2} \mathrm{P}=$ plant available phosphorus $($ Bray) $; \mathrm{K}=$ potassium; $\mathrm{Ca}=$ calcium; $\mathrm{Mg}=$ magnesium; $\mathrm{Na}=$ sodium; $\mathrm{CEC}=$ cation exchange capacity; $\mathrm{EC}=$ exchangable salts; $\mathrm{Fe}=$ iron $\mathrm{Mn}=$ manganese $; \mathrm{Cu}=$ copper $\mathrm{Zn}=$ zinc; $\mathrm{NH}-\mathrm{N}=$ ammonium-nitrogen $; \mathrm{NO}-\mathrm{N}=$ nitrate-nitrogen; $\mathrm{Cl}=$ chloride $; \mathrm{TC}=$ total carbon; $\mathrm{TN}=$ total nitrogen

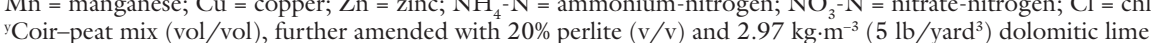

${ }^{x}$ Coir-peat mix ( $1.0 \mathrm{mg} \cdot \mathrm{kg}^{-1}=1.0 \mathrm{ppm} ; 1.0 \mathrm{cmol} \cdot \mathrm{kg}^{-1}=1.0 \mathrm{meq} / 100 \mathrm{~g} ; 1.0 \mathrm{dS} \cdot \mathrm{m}^{-1}=1.0 \mathrm{mmhos} / \mathrm{cm} ; 1.0 \mathrm{~g} \cdot \mathrm{kg}^{-1}=0.1 \%$.

${ }^{\mathrm{w} C o c o L i t e}=$ coir product from Sri Lanka; peat $=$ Lakeland peatmoss 
Table 2. Chemical analyses of leachates collected from coir-peat mixes without plants over the duration of the 6-week study.

\begin{tabular}{|c|c|c|c|c|c|c|c|c|c|c|c|c|c|}
\hline \multirow{2}{*}{$\begin{array}{l}\text { Coir-peat } \\
\text { treatment }^{\mathrm{y}}\end{array}$} & \multicolumn{12}{|c|}{ Chemical $\left[\mathrm{mg} \cdot \mathrm{kg}^{-1}(\mathrm{ppm})\right]^{\mathrm{z}}$} & \multirow{2}{*}{$\begin{array}{c}\text { EC } \\
\left(\mathrm{dS} \cdot \mathrm{m}^{-1}\right)\end{array}$} \\
\hline & $\mathbf{P}^{\mathrm{y}}$ & $\mathrm{PO}_{4}-\mathrm{P}$ & $\mathbf{K}$ & $\mathrm{Ca}$ & $\mathrm{Mg}$ & $\mathrm{Fe}$ & Mn & $\mathrm{Cu}$ & $\mathrm{Zn}$ & $\mathrm{NH}_{4}-\mathrm{N}$ & $\mathrm{NO}_{3}-\mathrm{N}$ & $\overline{\mathrm{Cl}}$ & \\
\hline \multicolumn{14}{|c|}{ Initial saturation $^{x}$} \\
\hline $0: 100$ & 9 & 6 & 20 & 23 & 10 & 0.14 & 0.39 & 0.04 & 0.35 & 5.9 & 4.0 & 16 & 0.34 \\
\hline $15: 85$ & 7 & 6 & 65 & 39 & 17 & 0.15 & 0.22 & 0.03 & 0.17 & 12.5 & 16.2 & 78 & 0.77 \\
\hline $30: 70$ & 6 & 5 & 126 & 37 & 17 & 0.15 & 0.20 & 0.02 & 0.04 & 0.6 & 15.2 & 157 & 1.09 \\
\hline $45: 55$ & 5 & 3 & 142 & 29 & 13 & 0.15 & 0.09 & 0.02 & 0.09 & 1.0 & 12.7 & 171 & 1.01 \\
\hline $60: 40$ & 4 & 3 & 158 & 16 & 8 & 0.15 & 0.04 & 0.02 & 0.04 & 0.2 & 1.4 & 193 & 1.12 \\
\hline \multicolumn{14}{|l|}{ Transplant } \\
\hline $0: 100$ & 8 & 6 & 79 & 108 & 40 & 0.15 & 0.09 & 0.18 & 0.18 & 10.8 & 150.6 & 8 & 0.49 \\
\hline $15: 85$ & 6 & 6 & 98 & 96 & 36 & 0.10 & 0.04 & 0.21 & 0.21 & 7.8 & 152.4 & 17 & 0.44 \\
\hline $30: 70$ & 4 & 4 & 131 & 50 & 20 & 0.07 & 0.01 & 0.16 & 0.16 & 0.5 & 208.4 & 21 & 0.42 \\
\hline $45: 55$ & 7 & 6 & 224 & 88 & 57 & 0.03 & 0.01 & 0.24 & 0.19 & 0.6 & 225.2 & 22 & 0.38 \\
\hline $60: 40$ & 3 & 2 & 184 & 26 & 10 & 0.07 & 0.01 & 0.17 & 0.17 & 0.7 & 98.5 & 23 & 0.53 \\
\hline \multicolumn{14}{|l|}{ Harvest } \\
\hline $0: 100$ & 9 & 7 & 228 & 138 & 56 & 0.08 & 0.03 & 0.24 & 0.24 & 1.8 & 223.8 & 8 & 2.02 \\
\hline $15: 85$ & 8 & 6 & 233 & 152 & 60 & 0.06 & 0.01 & 0.26 & 0.26 & 0.6 & 243.1 & 9 & 2.15 \\
\hline $30: 70$ & 8 & 5 & 226 & 130 & 56 & 0.03 & 0.02 & 0.25 & 0.25 & 0.9 & 221.9 & 9 & 2.01 \\
\hline $45: 55$ & 4 & 3 & 224 & 125 & 60 & 0.02 & 0.01 & 0.26 & 0.24 & 0.5 & 119.5 & 11 & 2.02 \\
\hline $60: 40$ & 7 & 6 & 228 & 48 & 17 & 0.01 & 0.01 & 0.29 & 0.29 & 0.7 & 220.6 & 9 & 1.98 \\
\hline
\end{tabular}

${ }^{2} \mathrm{P}=$ total phosphorus $\mathrm{PO}_{4}-\mathrm{P}=$ plant available phosphorus; $\mathrm{K}=$ potassium; $\mathrm{Ca}=$ calcium; $\mathrm{Mg}=$ magnesium; $\mathrm{Na}=$ sodium; $\mathrm{CEC}=$ cation exchange capacity; Fe = iron; $\mathrm{Mn}$ = manganese $\mathrm{Cu}=$ copper $; \mathrm{Zn}=$ zinc $; \mathrm{NH}_{4}-\mathrm{N}=$ ammonium-nitrogen $; \mathrm{NO}_{3}-\mathrm{N}=$ nitrate-nitrogen $; \mathrm{Cl}=$ chloride $; \mathrm{TC}=$ total carbon; $\mathrm{TN}=$ total nitrogen; $\mathrm{EC}=$ exchangable salts; $1.0 \mathrm{dS} \cdot \mathrm{m}^{-1}=1.0 \mathrm{mmos} / \mathrm{cm}$.

Coir-peat mix (v/v), further amended with $20 \%$ perlite $(\mathrm{v} / \mathrm{v})$ and $2.97 \mathrm{~kg} \cdot \mathrm{m}^{-3}\left(5 \mathrm{lb} / \mathrm{yard}^{3}\right)$ dolomitic lime.

Analyses of leachates taken after initial saturation; at transplant, after four water leachings; and at harvest, simulating the complete water and fertilizer regiment applied to nonplanted containers during a 6-week study.

study without mediation by a plant. The complex natures of peat and coir are likely compounded within these mixes. Given coir's inherently higher amounts of $\mathrm{K}, \mathrm{Na}$, and $\mathrm{Cl}$ relative to peat's higher amounts of $\mathrm{Ca}, \mathrm{Mg}, \mathrm{Fe}$, $\mathrm{Mn}$, and $\mathrm{N}$ forms, and with the addition of water-soluble fertilizers, the exchange of nutrients in these mixes may cause $\mathrm{pH}$ fluctuations over longer periods of time, affecting plant sensitivity and response. Other nutrient concentrations in our study fluctuated (Tables 1 and 2) but are not easily compared to other studies because of the differences in mixes and the inconsistencies in the physicochemical nature of the coirs and plant growth responses.

Coir, mycorrhiza, and their interaction showed significant influence on growth of the assayed hosts (Table 3 ). Coir amendment significantly affected shoot biomass of all host plants, but response varied with plant species (Fig. 1). Zinnia and marigold grew equally well across all coir levels in non-AM treatments. Zinnia grew slightly larger at the $45 \%$ coir rate in AM treatments. Lavender growth in both AM and non-AM media was significantly less when as little as $15 \%$ coir was added. Shoot biomass of nonAMroses decreased when planted in 30\% or higher rates of coir. In contrast, AM rose plant biomass increased at the $45 \%$ and $60 \%$ coir rates.

The AM growth effect itself was not always significant, whether as a single factor or interactive with coir
(Table 3 ). With the varied patterns of growth responses, generalizations are difficult. However, a significant growth increase occurred at the $45 \%$ rate for all AM host plants compared to the nonAM plants (Fig. 1).

AM colonization over the range of host plants was also variable, but was significantly influenced by rate of coir amendment (Table 3; Fig. 1). Colonization percentages were the lowest in $0 \%$ coir and highest in $45 \%$ coir.

While AM colonization was negligible with little or no coir present in the mix, shoot growth was sometimes greater when coir was absent. Several explanations are possible from the microbiological viewpoint. First, all non-AM control plants were treated with filtrates from the $G$. intraradices inoculum, which may have contributed plant growth-promoting rhizosphere (PGPR) microorganisms not otherwise found in the peat-coir media (Andrade et al., 1997). These microbes may have been stimulated more by peat than by coir, and thus were responsible for enhancing growth, while the AM fungus itself was not stimulated.

Second, the microbes present either in coir or stimulated by coir also should be considered. Although we did not assess microbial populations in this study, other work in progress indicates that populations of antagonistic bacteria and other groups of rhizosphere microbes differ substantially between sources and brands of coir mixes (Linderman, Marlow, and
Davis, unpublished).

Differences in plant growth in response to coir have been attributed to a generally higher initial moisture holding capacity relative to peat (Meerow, 1995). However, peat may have an increased moisture holding capacity over a longer period of time. Although we did not specifically monitor such capacity in our studies, we visually and manually sensed plant moisture needs and thereby maintained similar moisture contents between treatments. Thus, it is unlikely that any slight moisture differences in the media mixtures would have had any pronounced effect on the growth effects or AM root colonizations.

The interactions of the physicochemical and microbiological aspects of coir, along with individual host responses to mycorrhizal inoculation, also may contribute to variable results. In previous studies, we found these cultivars of lavender, rose, and germander to be highly growth-responsive to inoculation with this same Glomus intraradices isolate when grown in a P-limited sandy-loam-peat mix. Cultivars of marigold or zinnia were not included in those studies. After finishing this experiment, we determined that the 'Peter Pan' zinnia hybrid used here is not very AM-responsive compared to other zinnia hybrids.

\section{Conclusion}

The conclusion drawn from this study is that coir amendment to a peat- 
Table 3. Analysis of variance probability values describing effects of coir rate $(C)$ and mycorrhiza (AM) on growth parameters of bioassay hosts and percentage of roots with Glomus intraradices colonization.

\begin{tabular}{|c|c|c|c|c|c|}
\hline \multirow[b]{2}{*}{ Host } & \multirow[b]{2}{*}{$\begin{array}{l}\text { Source } \\
\text { factor }\end{array}$} & \multicolumn{4}{|c|}{$P^{z}$} \\
\hline & & $\begin{array}{l}\text { Shoot } \\
\text { biomass } \\
\text { (S) }\end{array}$ & $\begin{array}{c}\text { Root } \\
\text { biomass } \\
\text { (R) }\end{array}$ & $\mathrm{R}: \mathrm{S}$ & Colonization \\
\hline \multirow[t]{3}{*}{ Marigold } & $\mathrm{C}$ & $<0.001$ & $<0.001$ & $<0.001$ & $<0.001$ \\
\hline & $\mathrm{AM}$ & 0.508 & $<0.001$ & 0.001 & \\
\hline & $\mathrm{C} \times \mathrm{AM}$ & 0.626 & 0.631 & 0.360 & \\
\hline \multirow[t]{3}{*}{ Zinnia } & $\mathrm{C}$ & 0.033 & 0.006 & 0.007 & $<0.001$ \\
\hline & $\mathrm{AM}$ & 0.049 & 0.491 & 0.727 & \\
\hline & $\mathrm{C} \times \mathrm{AM}$ & 0.004 & $<0.001$ & 0.036 & \\
\hline \multirow[t]{3}{*}{ Germander } & $\mathrm{C}$ & $<0.001$ & $<0.001$ & 0.019 & $<0.001$ \\
\hline & $\mathrm{AM}$ & 0.186 & 0.002 & 0.035 & \\
\hline & $\mathrm{C} \times \mathrm{AM}$ & 0.004 & 0.008 & 0.732 & \\
\hline \multirow[t]{3}{*}{ Lavender } & $\mathrm{C}$ & $<0.001$ & $<0.001$ & 0.584 & $<0.001$ \\
\hline & $\mathrm{AM}$ & 0.006 & $<0.001$ & 0.001 & \\
\hline & $\mathrm{C} \times \mathrm{AM}$ & 0.832 & 0.664 & 0.360 & \\
\hline \multirow[t]{3}{*}{ Miniature-rose } & C & $<0.001$ & 0.012 & 0.127 & $<0.001$ \\
\hline & $\mathrm{AM}$ & 0.510 & 0.510 & 0.003 & \\
\hline & $\mathrm{C} \times \mathrm{AM}$ & 0.009 & 0.009 & 0.277 & \\
\hline
\end{tabular}

${ }^{2}$ Analyses of log-transformed biomass data and arcsin-transformed colonization data.

based medium influences plant growth, possibly due to its nutrient-binding properties, and growth responses will vary depending upon the plant. Colonization by the AM fungus, $G$. intraradices, was also affected by coir amendment, often increasing with more coir in the mix, to a maximum of $45 \%$ coir amendment to peat. Our study documents potential effects of coir on the activity of one AM fungus on a select small group of host bedding plants. While considerable variation exists in the chemical properties of different coirs, more important may be differences in microbiological properties. The complex nature of coir and the diverse results reported in the literature justify more

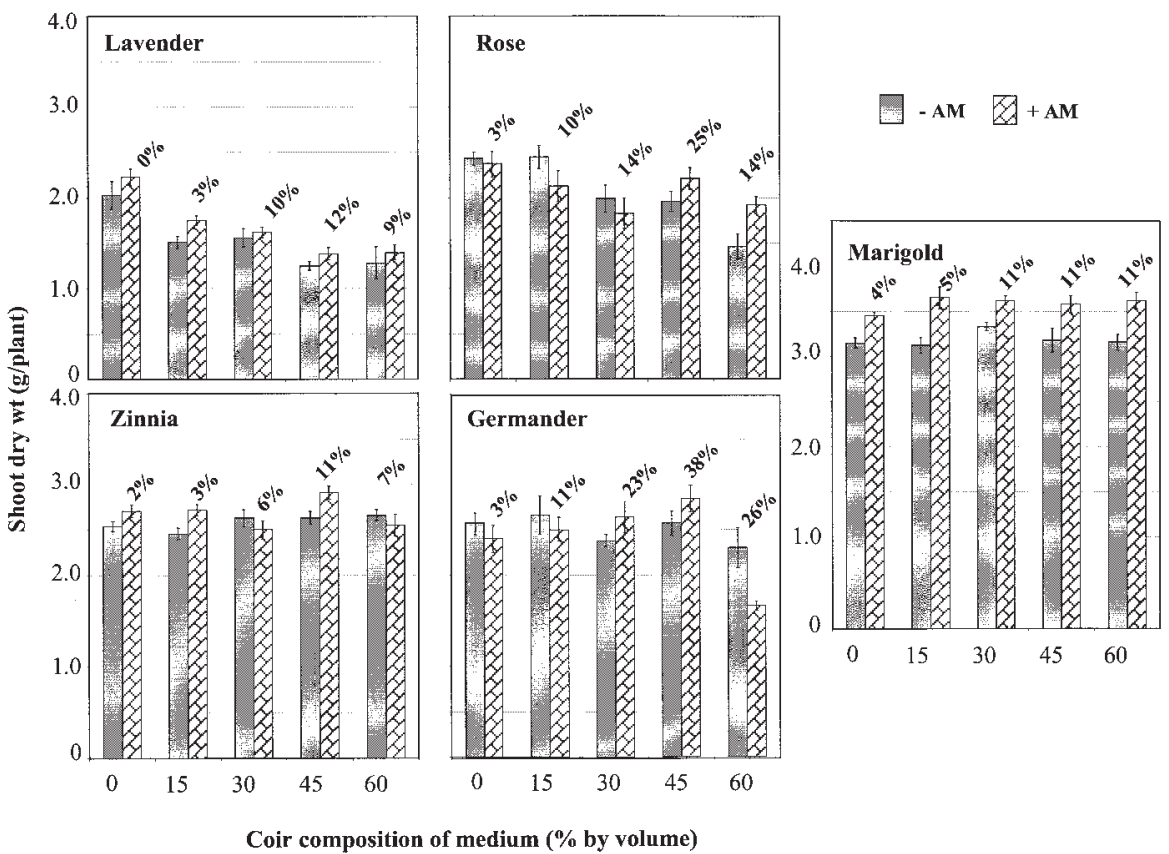

Fig. 1. Shoot biomass and percentage root colonization by the arbuscular mycorrhizal (AM) fungus, Glomus intraradices, for five horticultural plants grown in increasing levels of coir amended to a potting medium of peat and perlite. Vertical bars represent standard error $(n=6)$. Percentages over columns indicate the percent of root length with AM colonization. examination of this unique amendment, particularly with respect to potential effects on rhizosphere organisms, as well as elucidation of appropriate potting media mix and fertilizer regimes.

\section{Literature cited}

Abad, M., P. Noguera, R. Puchades, A Maquieira, and V. Noguera. 2002. Physicochemical and chemical properties of some coconut coir dusts for use as a peat substitute for containerised ornamental plants. Bioresour. Technol. 82:241-245.

Andrade, G., K.L. Mihara, R.G. Linderman, and G.J. Bethlenfalvay. 1997. Bacteria from rhizosphere and hyphosphere soils of different arbuscular-mycorrhizal fungi. Plant Soil 192:71-79.

Argo, W.R. and J.A. Biernbaum. 1995. Root-medium nutrient levels and irrigation requirements of poinsettias grown in five root media. HortScience 30:535-538.

Argo, W.R. and J.A. Biernbaum. 1997. The effect of root media on root-zone $\mathrm{pH}$, calcium, and magnesium management in containers with Impatiens. J. Amer. Soc. Hort. Sci. 122:257-284.

Biermann, B. and R.G. Linderman. 1983a. Increased geranium growth using pretransplant inoculation with a mycorrhizal fungus. J. Amer. Soc. Hort. Sci. 108(6):972-976.

Biermann, B. and R.G. Linderman. 1983b. Effect of container plant growth medium and fertilizer phosphorus on establishment and host growth response to vesicular-arbuscular mycorrhizae. J. Amer. Soc. Hort. Sci. 108(6):962-971.

Brundrett, M. 1991. Mycorrhizas in natura ecosytems. Adv. Ecol. Res. 21:171-313.

Cantrell, I.C. and R.G. Linderman. 2001. Preinoculation of lettuce and onion with VA mycorrhizal fungi reduces deleterious effects of soil salinity. Plant and Soil 233 269-281

Chang, D.C.N. 1992. What is the potential for management of vesicular-arbuscular mycorrhizae in horticulture, p. 187-190 In: A.D. Robson, L.K. Abbott, and N. Malajczuk (eds.). Proc. Intl. Symp. Management of Mycorrhizas in Agriculture, Horticulture, and Forestry, Perth, Western Australia. Kluwer, Dordrecht, The Netherlands.

Datnoff, L.E., S. Nemec, and R.N. Reid. 1991. Influence of various vegetable potting mixes on colonization of tomato by Glomus intraradix. Proc. Fla. State Hort. Soc. 104:253-289.

Evans, M.R. and J.K. Iles. 1997. Growth of Viburnum dentatum and Syringa $\mathrm{x}$ prestoniae 'Donald Wyman' in sphagnum peat and coir dust-based substrates. J. Environ. Hort. 15:156-159.

Horílectunology • July-September 2003 13(3) 
Evans, M.R. and R. Stamps. 1994. Growth of annual species in coconut coir substrates. HortScience 29:501 (abstr.).

Evans, M.R. and R.H. Stamps. 1997. Growth of bedding plants in sphagnum peat and coir dust-based substrates. J. Environ. Hort. 14:187-190.

Evans, M.R., S. Konduru, and R.H. Stamps. 1996. Source variation in physical and chemical properties of coconut coir dust. HortScience 31:965-967.

Giovannetti, M. and B. Mosse. 1980. An evaluation of techniques for measuring vesicular-arbuscular mycorrhizal infection in roots. New Phytol. 489-500.

Graham, J.H. and L.W. Timmer. 1984. Vesicular-arbuscular mycorrhizal development and growth response of rough lemon in soil and soilless media: effect of phosphorus source. J. Amer. Soc. Hort. Sci. 109:118-121.

Handreck, K.A. 1993. Properties of coir dust, and its use in the formulation of soilless potting media. Commun. Soil Sci. Plant Anal. 24:349-363.

Hunter, M.N. 1997. Mycorrhizae the wonder fungi. Austral. Hort. 95:96-103.

Kithome, M., J.W. Paul, and T. Kannangara. 1999. Adsorption isotherms of ammonium on coir. Commun. Soil Sci. Plant Anal. 30: 83-95.

Knight, P.R., J.M. Anderson, and R.A. Parks. 1998. Impact of coir-based media in Azalea growth. Proc. Southern Nursery Assn. Res. Conf. 43:28-31.

Konduru, S., M.R. Evans, and R.H. Stamps. 1999. Coconut husk and processing effects on chemical and physical properties of Coconut coir dust. HortScience 34:88-90.

Linderman, R.G. 1994. Role of VAM fungi in biocontrol, p. 1-26 In: F.L. Pfleger and R.G. Linderman (eds.). Mycorrhizae and plant health., APS Press, St. Paul, Minn.

Linderman, R.G. 2000. Effects of mycorrhizas on plant tolerance to diseases, $p$ 345-365 In: Y. Kapulnik and D.D. Douds (eds.). Arbuscular mycorrhizas: Physiology and function., Kluwer, Dordrecht, The Netherlands.

Linderman, R.G. and E.A. Davis. 2001. Vesicular-arbuscular mycorrhiza and plant growth response to soil amendment with composted grape pomace or its water extract. HortTechnology 11(3):446-450.

Linderman, R.G. and E.A. Davis. 2003. Soil amendment with different peatmosses affects mycorrhizae of onion. Hort Technology 13(2):285-289.

Meerow, A.W. 1994. Growth off two subtropical ornamentals using coir (coconut mesocarp pith) as a peat substitute. HortScience 29:1484-1486.

Meerow, A.W. 1995. Growth of two tropical foliage plants using coir dust as a container medium amendment. HortTechnology 5: 237-239.

Noguera, P., M. Abad, R. Puchades, V. Noguera, A. Maquiera, and J. Martinez. 1997. Physical and chemical properties of coir waste and their relation to plant growth. Acta Hort. 450:365-373.

Offord, C.A., S. Muir, and J.L. Tyler. 1998. Growth of selected Australian plants in soilless media using coir as a substitute for peat. Austral. J. Expt. Agr. 38:879-887.

Petersen, R.G. 1985. Design and analysis of experiments. Marcel Dekker, New York.

Phillips, J.M. and D.S. Hayman. 1970. Improved procedures for clearing roots and staining parasitic and vesicular-arbuscular mycorrhizal fungi for rapid assessment of infection. Trans. Br. Mycol. Soc. 55: 158-161

Pill, W.G. and K.T. Ridley. 1998. Growth of tomato and coreopsis in response to coir dust in soilless media. HortTechnology 8: 401-405.

Prince, W.-SPM., S. Sivakumar, V. Ravi, and V. Subburam. 2000. The effects of coirpith compost on the growth and quality of leaves of the mulberry plant Morus alba L. Bioresour. Technol. 72:95-97.

Raviv, M., J.H. Lieth, D.W. Burger, and R. Wallach. 2001. Optimization of transpiration and potential growth rates of 'Kardinal' rose with respect to root-zone physical properties. J. Amer. Soc. Hort. Sci. 126:638-643.

Smith, S.E. and D.J. Read. 1997. Mycorrhizal symbiosis. Academic Press, Cambridge, U.K.

Stamps, R.H. and M.R. Evans. 1997. Growth of Dieffenbachia maculata 'Camille' in growing media containing sphagnum peat or coconut coir dust. HortScience $32: 844-874$

Stamps, R.H. and M.R. Evans. 1999. Growth of Dracaena marginata and Spathiphyllum 'Petite' in sphagnum peatand coconut coir dust-based growing media. J. Environ. Hort. 17:49-52.

Waber,A.A. and M.R. Evans. 1996. Growth and development of Euphobia pulcherrima 'Freedom' and Lilium longiflorum 'Nellie White' in sphagnum peat- and coir dustbased substrates. HortScience 31:657 (abstr.).

Woomer, P.L. 1994. Most probable number counts, p. 59-79. In: R.W. Weaver (ed.). Methods of soil analysis. Part 2. Soil Sci. Soc. Amer., Madison, Wis.
Sowing Dates and Priming Influence African Marigold Field Emergence

\author{
Theresa L. Bosma, \\ Kenneth E. Conway, ${ }^{2}$ \\ John M. Dole ${ }^{1,3}$ and \\ Niels O. Maness ${ }^{1}$
}

AdDitional INDEX wORDs. african marigolds, solid matrix priming, osmotic priming, emergence time, emergence uniformity, total emergence percentage, direct-seeded, stand establishment, Tagetes evecta

Summary. Field seedling emergence of four african marigold (Tagetes erecta) breeding lines, A-975, E-1236, I-822, and 'Orange Lady', was examined using three or four spring sowing dates and either osmotic or solid matrix priming. Delayed sowing decreased emergence time. Sowing from middle to late April [average soil temperatures 77.0 to $84.2^{\circ} \mathrm{F}\left(25\right.$ to $\left.29^{\circ} \mathrm{C}\right)$ ] resulted in the highest total emergence percentages. Greater flower quantities [4.9 to 5.1 million/acre ( 12.11 to 12.60 million/ha)] and estimated yield [7.5 to 10.8 tons/acre (16.81 to $24.20 \mathrm{t} \cdot \mathrm{ha}^{-1}$ )] indicate mid to late April is the optimum time period for direct sowing unprimed seed in the southern Great Plains. Differences between lines were evident in emergence parameters and flower harvest data for each year examined, but results were inconsistent from year to year. However, A-975 and E-1236 produced harvestable flowers most quickly, about $15 \mathrm{~d}$ before I-822, which could result in an additional harvest during a season. Osmotic priming of E-1236 and I-822 seed shortened emergence time, increased emergence uniformity, and increased total emergence percentage at early sowing dates as compared to both solid matrix primed and unprimed seed.

${ }^{1}$ Department of Horticulture and Landscape Archi tecture, Oklahoma State University, Stillwater, OK 74078-6027

${ }^{2}$ Department of Entomology and Plant Pathology, Oklahoma State University, Stillwater, OK 74078-6027. ${ }^{3}$ Present address: Department of Horticultural Sciences, North Carolina State University, Raleigh, NC 27695-7609 